\title{
PENGARUH NILAI TUKAR, INFLASI, VOLUME PERDAGANGAN, DAN DIVIDEND PAYOUT RATIO TERHADAP SHARE PRICE VOLATILITY PADA PERUSAHAAN YANG TERDAFTAR DALAM INDEKS KOMPAS100 TAHUN $2014-2018$
}

\author{
Mastura $^{1}$, Mursyida ${ }^{2}$
}

\begin{abstract}
This research aims to analyze partial and simultaneous influence between exchange rate, inflation, trading volume, and dividend payout ratio to share price volatility in Kompas100 index. This research uses 23 companies listed in Kompas100 index as a research sample during the period of 2014 to 2018, where sampling uses purposive sampling technique. In order to analyze, and test each research hypotheses, the technique used is panel data regression using the random effect model. The results of data analysis show that partially, the excgange rate, inflation, and trading volume have a positive and significant effect to share price volatility while the dividend payout ratio has a negative and significant effect to share price volatility. the results of data analysis show simultaneously, the exchange rate, inflation, trading volume, and dividend payout ratio have significant influence to share price volatility. The amount of testing the coefficient of determinastion (adjusted $R$ square) is 0.416174 , indicating that dependen variable which is share price volatility can be explained by independent variables those are exchange rate, inflation, trading volume, and dividend payout ratio was $41.6 \%$, while $58.4 \%$ can be explained by the other variables outside the models
\end{abstract}

Keywords: Dividend Payout Ratio, Exchange Rate, Inflation, Trading Volume, Share Price Volatility

\footnotetext{
${ }^{1}$ IAIN Langsa, mastura@iainlangsa.ac.id

${ }^{2}$ IAIN Langsa, mursyida_cr7lovers@gmail.co.id
} 


\section{PENDAHULUAN}

Investasi merupakan suatu kegiatan penanaman modal/dana yang dilakukan oleh seseorang yang bertujuan untuk memperoleh hasil berupa keuntungan di masa yang akan datang. Melalui investasi, perekonomian suatu negara akan berkembang dan pendapatan masyarakat juga akan meningkat. Islam tidak memperbolehkan penimbunan harta kekayaan. Untuk itu, investasi sangat dianjurkan untuk menghindari adanya penimbunan harta kekayaan yang tidak produktif. Salah satu bentuk investasi yang bisa dilakukan yaitu investasi saham di pasar modal.

Dalam berinvestasi saham, investor tidak boleh hanya terpaku pada return yang akan didapatkan. Tetapi juga harus memperhatikan tingkat risiko yang akan dihadapi yang melekat dalam berinvestasi saham. Pasar modal sangat sensitif terhadap setiap peristiwa atau isu-isu yang beredar disekitarnya. Perkembangan pasar modal yang sering berubah-ubah memberikan dampak bagi investor untuk lebih berhati-hati dalam memilih untuk menjual atau membeli saham. Selain memperhatikan faktor return dan risiko, dalam berinvestasi investor juga akan mengumpulkan berbagai informasi terutama yang berkaitan dengan harga saham. Harga saham menjadi dasar pertimbangan bagi investor karena harga saham mencerminkan nilai perusahaan. Semakin tinggi harga saham berarti semakin tinggi pula nilai perusahaanya, begitupun sebaliknya.

Harga saham dapat mengalami kenaikan maupun penurunan yang disebabkan oleh aktifitas perdagangan di pasar modal. Peningkatan permintaan saham akan mendorong kenaikan harga saham, begitupun sebaliknya. Jika investor banyak melakukan aktivitas penjualan maka hal tersebut akan mendorong penurunan harga saham. Permintaan dan penawaran tersebut mengakibatkan harga saham berubah-ubah setiap waktu. Perubahan harga saham tersebut dikenal dengan istilah volatilitas harga saham (share price volatility).

Volatilitas harga saham (share price volatility) adalah pengukuran statistik untuk fluktuasi harga saham selama kurun waktu tertentu. Pada dasarnya, volatilitas harga mencerminkan tingkat risiko yang akan dihadapi oleh investor. Semakin tinggi tingkat volatilitas maka semakin besar kemungkinan harga saham naik dan turun secara cepat. Semakin tinggi tingkat volatilitas harga saham maka ketidakpastian return yang akan diterima juga semakin tinggi. Meskipun demikian, sebagian investor cenderung menyukai saham dengan tingkat volatilitas yang tinggi karena peluang dalam mendapatkan capital gain akan semakin besar walaupun risiko kerugian yang akan diterima juga akan semakin besar. Volatilitas harga yang tinggi biasanya disukai oleh trader jangka pendek yang menginginkan return berupa capital gain yang besar. Sedangkan untuk saham dengan volatilitas harga yang rendah cenderung disukai oleh investor jangka panjang yang menginginkan kestabilan nilai return.

Pergerakan tinggi rendahnya harga saham dapat dipengaruhi oleh berbagai faktor seperti faktor mikroekonomi dan makroekonomi. faktor mikroekonomi adalah faktor 
yang langsung berdampak terhadap perusahaan itu sendiri, seperti perubahan manajemen, harga dan ketersediaan bahan baku, produktivitas tenag, serta pengumuman laporan keuangan dan dividen. Faktor makroekonomi adalah faktor yang dapat mempengaruhi perekonomian secara menyeluruh, seperti tingkat suku bunga, nilai tukar, inflasi, tingkat produktivitas nasional, politik, dan faktor lainnya yang berdampak pada potensi keuntungan perusahaan.

Sebelumnya, telah banyak peneliti yang melakukan riset tentang faktor-faktor yang mempengaruhi volatilitas harga saham diantaranya yaitu Naimatul Fauziah tahun 2013 menemukan bahwa volume perdagangan dan inflasi berpengaruh positif signifikan terhadap volatilitas harga saham sedangkan dividend payout ratio berpengaruh negatif signifikan terhadap volatilitas harga saham. Irma Rohmawati tahun 2017 menemukan bahwa volume perdagangan dan dividend payout ratio berpengaruh positif dan signifikan terhadap volatilitas harga saham sedangkan inflasi tidak berpengaruh terhadap volatilitas harga saham. Lidyanita Hugida tahun 2011 menemukan bahwa nilai tukar, inflasi, dan volume perdagangan berpengaruh secara positif signifikan terhadap volatilitas harga saham.

\section{Share Price Volatility}

Share price volatility atau disebut juga volatilitas harga saham adalah fluktuasi atau naik dan turunnya harga saham pada suatu periode tertentu. Definisi lain dari share price volatility adalah suatu risiko sistematik yang hanya dihadapi oleh investor yang menanamkan modalnya pada saham biasa. Share price volatility biasanya terjadi karena adanya informasi baru yang masuk kedalam bursa. Hal tersebut mengakibatkan para pelaku pasar melakukan penilaian kembali terhadap aset yang akan diperdagangkan. Share price volatility dapat menjadi ukuran dalam menentukan risiko dalam berinvestasi dan dapat menunjukkan tingkat perubahan stock price selama jangka waktu tertentu.

Volatilitas terdiri dari dua jenis, yaitu:

a. Transitory volatility, yaitu volatilitas yang bersifat sementara. Hal tersebut terjadi karena adanya ketidakseimbangan arus order, seperti kepemilikan pasar dan ekspektasi yang berlebihan. Selain itu, transitory volatility juga dapat terjadi karena adanya pihak tertentu yang berspekulasi membeli atau menjual komoditas dalam jumlah besar.

b. Fundamental volatility, yaitu volatilitas yang tidak dapat dihindari yang disebabkan karena faktor-faktor fundamental seperti bencana alam, kegagalan panen, dan serangan hama.

Untuk menghitung volatilitas harga saham, rumus yang digunakan adalah:

$$
\text { PVOL }=\sqrt{\sum \frac{\left(\frac{(H i-L i)}{\left(\frac{H i+L i}{2}\right)}\right)^{2}}{12}}
$$


Keterangan:

PVOL = Price Volatility

$\mathrm{Hi}=$ Intraday High price

$\mathrm{Hl} \quad=$ Intraday Low Price

\section{Nilai Tukar}

Nilai tukar Rupiah atau disebut juga kurs Rupiah adalah perbandingan nilai atau harga mata uang Rupiah dengan mata uang lain. Perdagangan antar negara dimana masing-masing negara mempunyai alat tukarnya sendiri mengharuskan adanya angka perbandingan nilai suatu mata uang dengan mata uang lainnya, yang disebut kurs valuta asing atau kurs. Sedangkan menurut pendapat lain, mengatakan bahwa kurs atau nilai tukar adalah harga dari mata uang luar negeri.

Nilai tukar atau biasa juga disebut sebagai valuta asing dalam berbagai transaksi atau jual beli valuta asing, ada empat jenis yaitu:

a. Selling rate (kurs jual), yaitu kurs yang ditentukan oleh suatu bank untuk penjualan valuta asing tertentu pada saat tertentu.

b. Middle rate (kurs tengah), yaitu kurs tengah antara kurs jual dan kurs beli valuta asing terhadap mata uang nasional, yang ditetapkan oleh bank sentral pada suatu saat tertentu.

c. Buying rate (kurs beli), yaitu kurs yang ditentukan oleh suatu bank untuk pembelian valuta asing tertentu pada saat tertentu.

d. Flat rate (kurs flat), yaitu kurs yang berlaku dalam transaksi jual beli bank notes dan traveler chaque, dimana dalam kurs tersebut telah diperhitungkan promosi dan biaya lain-lain.

\section{Inflasi}

Inflasi adalah suatu keadaan perekonomian dimana harga-harga secara umum mengalami kenaikan dalam waktu yang panjang. Kenaikan harga yang bersifat sementara seperti kenaikan harga pada masa lebaran tidak dianggap sebagai inflasi karena disaat setelah masa lebaran, harga-harga dapat turun kembali. Inflasi secara umum dapat terjadi karena jumlah uang beredar lebih banyak daripada yang dibutuhkan. kenaikan harga-harga (inflasi) dapat mengakibatkan nilai uang yang ada menjadi turun (devaluasi), sehingga berdampak pada tingkat konsumsi masyarakat.

Menurut BI, faktor penyebab adanya inflasi ada 3 (tiga) macam, yaitu:

a. Tekanan dari sisi penawaran/supply (cost push inflation)

b. Tekanan dari sisi permintaan/demand (demand pull inflation)

c. Kombinasi permintaan dan penawaran (demand-supply inflation) 


\section{Volume Perdagangan}

Volume perdagangan saham adalah banyaknya lembaran saham suatu emiten yang diperjualbelikan di pasar modal setiap hari dengan tingkat harga yang disepakati oleh pihak penjual dan pembeli saham. Data mengenai volume perdagangan ini penting untuk diamati karena apabila dibandingkan dengan total lembar saham beredar, dapat menunjukkan likuid tidaknya saham-saham diperjualbelikan di atas bursa.

Volume pedagangan yang dimaksud dalam penelitian ini adalah jumlah lembar saham yang diperdagangkan secara harian. Volume perdagangan ini kemudian dijadikan data tahunan dengan cara menjumlahkan seluruh lembar saham harian kemudian dibagi dengan jumlah hari aktif bursa pada tahun tersebut.

\section{Dividend Payout Ratio (DPR)}

Dividend Payout Ratio adalah jumlah dividend per lembar saham dibagi dengan jumlah pendapatan per lembar saham per tahun. Pendapat lain mengatakan bahwa dividend payout ratio adalah persentase tertentu dari laba perusahaan yang dibayarkan sebagai dividen kas kepada pemegang saham. dividend payout ratio memberikan gambaran seberapa besar kontribusi perusahaan terhadap pembayaran dividend. Semakin besar rasio dividend, maka semakin besar pula alokasi keuntungan perusahaan untuk pemegang saham.

Rumus yang digunakan untuk menghitung besarnya dividend payout ratio adalah sebagai berikut:

$$
D P R=\frac{\text { Dividen Per Share }}{\text { Earning Per Share }} x 100 \%
$$

\section{Kerangka Teoritis dan Hipotesis}

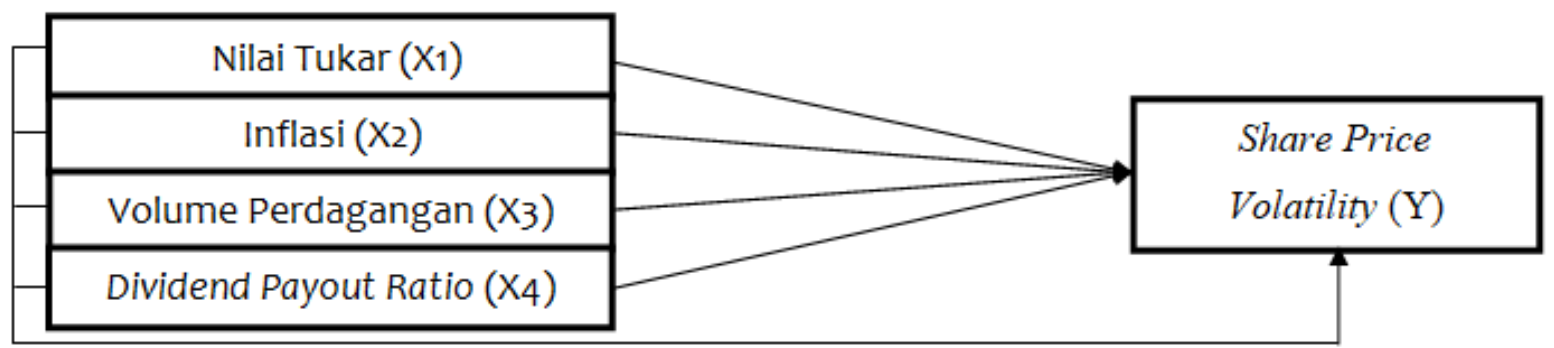

\section{Gambar 1. Kerangka Teoritis}

Adapun hipotesis yang diajukan dalam penelitian ini adalah sebagai berikut:

$\mathrm{H}_{1}$ : Diduga nilai tukar berpengaruh signifikan terhadap share price volatility.

$\mathrm{H}_{2}$ : Diduga inflasi berpengaruh signifikan terhadap share price volatility.

$\mathrm{H}_{3}$ : Diduga volume perdagangan berpengaruh signifikan terhadap share price volatility. 
IHTIYATH Jurnal Manajemen Keuangan Syariah

Vol. 5 No. 1, September 2021

$\mathrm{H}_{4}$ : Diduga dividend payout ratio berpengaruh signifikan terhadap share price volatility.

$\mathrm{H}_{5}$ : Diduga nilai tukar, inflasi, volume perdagangan, dan dividend payout ratio berpengaruh signifikan terhadap share price volatility

\section{METODE PENELITIAN}

Penelitian ini merupakan penelitian kuantitatif dengan menggunakan data sekunder berupa time series dan cross section. Dalam penelitian ini yang menjadi populasi adalah seluruh perusahaan yang terdaftar di indeks Kompas100 periode 2014 2018. Sampel dalam penelitian ini adalah 23 perusahaan. Pengambilan sampel tersebut menggunakan metode purposive sampling. Analisa statistic yang digunakan adalah regresi data panel dengan random effect model dengan persamaan sebagai berikut:

$$
Y_{i t}=a+b_{1} x_{1 i t}+b_{2} x_{2 i t}+b_{3} x_{3 i t}+b_{4} x_{4 i t}+\varepsilon_{i t}
$$

Keterangan :

$$
\begin{aligned}
& \mathrm{Y}=\text { Share Price Volatility } \\
& x_{1}=\text { Nilai Tukar } \\
& x_{2}=\text { Inflasi } \\
& x_{3}=\text { Volume Perdagangan } \\
& x_{4}=\text { Dividend Payout Ratio } \\
& \mathrm{a} \quad=\text { Bilangan Konstanta } \\
& \mathrm{b} \quad=\text { Koefisien Regresi } \\
& \mathrm{i} \quad=\text { perusahaan } \\
& \mathrm{t}=\text { waktu } \\
& \varepsilon_{i t}=\text { standar eror }
\end{aligned}
$$

\section{HASIL DAN PEMBAHASAN}

\section{Statistic Deskriptif}

Berikut ini disajikan statistik deskriptif dari setiap variabel bebas maupun variabel terikat guna mengetahui karakteristik masing-masing variabel yang meliputi mean, median, nilai minimum, nilai maksimum, dan standar deviasi. 
Table 4.1

Statistik Deskriptif Data Penelitian

\begin{tabular}{|l|l|l|l|l|l|}
\hline & $\begin{array}{l}\text { Share price } \\
\text { volatility }\end{array}$ & Nilai Tukar & Inflasi & $\begin{array}{l}\text { Volume } \\
\text { Perdagangan }\end{array}$ & DPR \\
\hline Mean & 0.061345 & 13263.60 & 0.046640 & 25972755 & 0.340521 \\
\hline Median & 0.060300 & 13399.00 & 0.038100 & 19015259 & 0.335000 \\
\hline Maximum & 0.099600 & 14248.00 & 0.064200 & 97948850 & 0.913900 \\
\hline Minimum & 0.019700 & 11866.00 & 0.032000 & 2403970. & 0.058300 \\
\hline Std. Dev. & 0.021753 & 776.7342 & 0.014368 & 24789547 & 0.178736 \\
\hline Obsservations & 115 & 115 & 115 & 115 & 115 \\
\hline
\end{tabular}

Sumber: data diolah dengan eviews

Penentuan Model data Panel

Table 4.2

Uji Chow

\begin{tabular}{|l|l|l|l|}
\hline Effects Test & Statistic & d.f. & Prob. \\
\hline Cross-section F & 10.335575 & $(22,88)$ & 0.0000 \\
\hline Cross-section Chi-square & 146.791735 & 22 & 0.0000 \\
\hline
\end{tabular}

Sumber: data diolah eviews

Berdasarkan hasil pengujian Chow, diperoleh nilai probabilitas cross-section $\mathrm{F}$ 0.0000 dimana nilai tersebut lebih kecil dari 0.05 yang artinya $\mathrm{H}_{1}$ diterima. Maka model terbaik yang dipilih adalah fixed effect model.

Tabel 4.3

Uji Hausman

\begin{tabular}{|l|l|l|l|}
\hline Test Summary & Chi-Sq. Statistic & Chi-Sq. d.f. & Prob. \\
\hline & & & \\
Cross-section random & 0.000000 & 4 & 1.0000 \\
\hline
\end{tabular}

Sumber: data diolah dengan eviews

Berdasarkan hasil pengujian Hausman, diperoleh nilai probabilitas 1.0000 dimana nilai tersebut lebih besar dari 0.05 yang artinya $\mathrm{H}_{0}$ diterima. Maka model terbaik yang dipilih adalah random effect

Tabel 4.4

Uji lagrange Multiplier

\begin{tabular}{|l|l|l|l|}
\hline \multirow{2}{*}{ Breusch-Pagan } & \multicolumn{2}{|l|}{ Test Hypothesis } \\
\cline { 2 - 4 } & Cross-section & Time & Both \\
\hline & 65.86376 & 6.831993 & 72.69575 \\
\cline { 2 - 4 } & $(0.0000)$ & $(0.0090)$ & $(0.0000)$ \\
\hline
\end{tabular}

Sumber: data diolah dengan eviews 
IHTIYATH Jurnal Manajemen Keuangan Syariah

Vol. 5 No. 1, September 2021

Berdasarkan hasil pengujian tersebut, dapat dilihat bahwa nilai probabilitas BreuschPagan adalah 0.0000 dimana nilai tersebut lebih kecil dari 0.05 yang artinya $\mathrm{H}_{1}$ diterima. Maka model terbaik yang dipilih adalah random effect.

\section{Uji Asumsi Klasik}

\section{Gambar 4.1}

\section{Uji Normalitas}

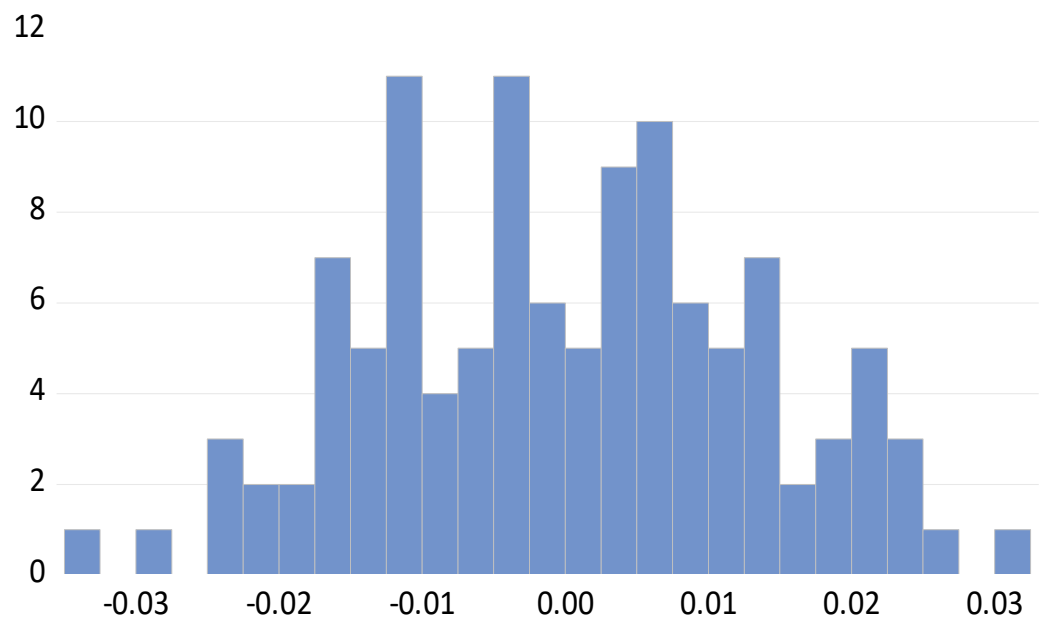

$\begin{array}{lc}\text { Series:Standardized Residuals } \\ \text { Sample } 20142018 \\ \text { Observations } & 115 \\ & \\ \text { Mean } & 9.58 \mathrm{e}-16 \\ \text { Median } & -0.000342 \\ \text { Maximum } & 0.030224 \\ \text { Minimum } & -0.032506 \\ \text { Std. Dev. } & 0.013328 \\ \text { Skewness } & 0.014686 \\ \text { Kurtosis } & 2.409957 \\ & \\ \text { Jarque-Bera } & 1.672357 \\ \text { Probability } & 0.433363\end{array}$

Sumber: data diolah dengan eviews

Berdasarkan output uji normalitas tersebut, terlihat bahwa nilai statistic J-B test adalah 1.672357 dan nilai probabilitasnya adalah 0.433363 dimana nilai tersebut lebih besar dari 0.05. Artinya data penelitian terdistribusi secara normal dan asumsi normalitas terpenuhi.

Tabel 4.5

Uji Multikolinearitas

\begin{tabular}{|l|l|l|l|l|}
\hline & Nilai Tukar & Inflasi & Volume & DPR \\
\hline Nilai Tukar & 1.000000 & -0.663096 & 0.038384 & -0.166989 \\
\hline Inflasi & -0.663096 & 1.000000 & -0.000802 & 0.060583 \\
\hline Volume & 0.038384 & -0.000802 & 1.000000 & -0.359642 \\
\hline DPR & -0.166989 & 0.060583 & -0.359642 & 1.000000 \\
\hline
\end{tabular}

Sumber: data diolah dengan eviews

Berdasarkan uji multikolinearitas tersebut, terlihat bahwa semua nilai korelasi antar variabel independen lebih kecil dari 0.8. Artinya, model regresi yang terbentuk terbebas dari asumsi multikolinearitas.

\section{Tabel 4.6}

\section{Uji Heterokedastisitas}

\begin{tabular}{|l|l|l|l|}
\hline F-statistic & 1.314953 & Prob. F(13,101) & 0.2167 \\
\hline Obs*R-squared & 16.64646 & Prob. Chi-Square(13) & 0.2160 \\
\hline Scaled explained SS & 9.864829 & Prob. Chi-Square(13) & 0.7049 \\
\hline
\end{tabular}

Sumber: data diolah dengan eviews 
Berdasarkan hasil pengujian heterokedastisitas, terlihat bahwa bahwa nilai probabilitas Chi-Square adalah sebesar 0.2160, dimana nilai tersebut lebih besar dari 0.05. maka dapat disimpulkan bahwa model regresi terbebas dari asumsi heterokedastisitas.

Tabel 4.7

Uji Autokorelasi

\begin{tabular}{|l|l|l|l|}
\hline F-statistic & 21.31591 & Durbin-Watson stat. & 1.624572 \\
\hline Prob (F-statistic) & 0.000000 & \\
\hline
\end{tabular}

Sumber: data diolah dengan eviews

Berdasarkan hasih uji autokorelasi, diperoleh nilai D-W sebesar 1.624572. sesuai dengan kriteria yang menyatakan bahwa jika nilai $\mathrm{D}-\mathrm{W}$ berada diantara -2 sampai dengan +2 atau $-2<1.624572<+2$, maka dapat disimpulakan bahwa model regresi terbebas dari asumsi autokorelasi.

\section{Hasil Analisa Regresi Data Panel}

Table 4.8

Hasil Regresi Data Panel

\begin{tabular}{|l|l|l|l|l|}
\hline Variable & Coefficient & Std. Error & t-Statistic & Prob. \\
\hline C & -1.112280 & 0.192491 & -5.778340 & 0.0000 \\
\hline Nilai Tukar & 0.108362 & 0.019358 & 5.597734 & 0.0000 \\
\hline Inflasi & 0.290577 & 0.074919 & 3.878540 & 0.0002 \\
\hline Volume Perdagangan & 0.008924 & 0.002464 & 3.621460 & 0.0004 \\
\hline DPR & -0.032649 & 0.011964 & -2.728997 & 0.0074 \\
\hline Adjusted R-squared & 0.416174 & \\
\hline F-Statistic & 21.31591 & \\
\hline Prob(F-statistic) & 0.000000 &
\end{tabular}

Sumber: data diolah dengan eviews

Berdasarkan hasil regresi data panel menggunakan estimasi random effect model untuk melihat seberapa besar pengaruh masing-masing variabel independen terhadap variabel dependen seperti yang terlihat pada tabel 4.14, dapat disimpulkan persamaan regresi sebagai berikut:

SPV $=-1.11228+0.10836(N T)+0.29057(\ln )+0.008924(V P)-0.032649(D P R)$

Interprestasi dari persamaan regresi diatas adalah sebagai berikut:

a. Nilai konstanta pada persamaan tersebut adalah -1.112280. Artinya, ketika semua variabel independen yang terdiri dari nilai tukar, inflasi, volume perdagangan, dan dividend payout ratio bernilai sama dengan 0 (nol), maka share price volatility akan bernilai bernilai $-1.11228 \%$. 
b. Nilai koefisien nilai tukar adalah 0.108362. Artinya, ketika nilai tukar terjadi peningkatan sebesar Rp1000 per \$1 dan variabel independen lainnya konstan maka share price volatility akan naik sebesar $0.108362 \%$.

c. Nilai koefisien inflasi adalah 0.290577. Artinya, ketika inflasi terjadi peningkatan sebesar $1 \%$ dan variabel independen lainnya konstan, maka share price volatility akan meningkat sebesar $0.290577 \%$.

d. Nilai koefisien volume perdagangan adalah 0.008924. Artinya, ketika volume perdagangan terjadi peningkatan 1 lembar dan variabel independen lainnya konstan, maka share price volatility akan meningkat sebesar $0.008924 \%$.

e. Nilai koefisien dividend payout ratio adalah -0.032649. Artinya, ketika dividend payout ratio terjadi peningkatan sebesar $1 \%$ dan variabel independen lainnya konstan, maka share price volatility akan menurun sebesar $0.032649 \%$.

\section{Hasil Uji Hipotes is}

Berdasarkan hasil uji simultan pada tabel 4.8, terlihat bahwa hasil probabilitas $\mathrm{F}$ statistic adalah sebesar 0.000000 yang berarti lebih kecil dari 0.05. Dengan mencari pada tabel F, diperoleh nilai F-tabel sebesar 2.45 sedangkan F-statistik sebesar 21.31591 yang artinya lebih besar dari F-tabel. Jadi dapat disimpulkan bahwa pada uji simultan variabel nilai tukar, inflasi, volume perdagangan, dan dividend payout ratio secara bersama-sama berpengaruh signifikan terhadap share price volatility.

Berdasarkan hasil uji parsial pada tabel 4.8, terlihat bahwa nilai t-statistik variabel nilai tukar adalah $5.597734>\mathrm{t}$-tabel yaitu 1.98177 dan nilai probabilitas sebesar 0.0000 dimana nilai tersebut $<0.05$. Maka dapat disimpulkan bahwa $\mathrm{H}_{1}$ diterima yang berarti nilai tukar memiliki pengaruh positif dan signifikan terhadap share price volatility. Nilai t-statistik variabel inflasi adalah $3.878540>$ t-tabel yaitu 1.98177 dan nilai probabilitas sebesar 0.0002 dimana nilai tersebut $<0.05$. maka dapat disimpulkan bahwa $\mathrm{H}_{2}$ diterima yang berarti inflasi memiliki pengaruh positif dan signifikan terhadap share price volatility. Nilai t-statistik variabel volume perdagangan adalah $3.621460>\mathrm{t}$-tabel yaitu 1.98177 dan nilai probabilitas sebesar 0.0004 dimana nilai tersebut $<0.05$. maka dapat disimpulkan bahwa variabel volume perdagangan memiliki pengaruh positif dan signifikan terhadap share price volatility. Nilai t-statistik variabel dividend payout ratio adalah $-2.728997>\mathrm{t}$-tabel yaitu 1.98177 dan nilai probabilitas sebesar 0.0074 dimana nilai tersebut $<0.05$. Nilai negatif pada t-statistik menunjukkan pengaruh negatif. Maka dapat disimpulkan bahwa variabel dividend payout ratio memiliki pengaruh negatif dan signifikan terhadap share price volatility.

Nilai Adjusted $R$ Square pada hasil regresi dalam penelitian ini yang ditunjukkan pada tabel 4.8 adalah 0.416174 . nilai tersebut menunjukkan bahwa kontribusi seluruh variabel independen dalam menjelaskan variabel dependen adalah sebesar $41.6 \%$, sedangkan sisanya $58.4 \%$ dijelaskan oleh variabel lain yang tidak termasuk kedalam model. 


\section{Interpretasi hasil}

Hipotesis pertama yang diajukan dalam penelitian ini adalah nilai tukar berpengaruh signifikan terhadap share price volatility. Berdasarkan hasil regresi yang terlihat pada tabel 4.8, nilai probabilitas variabel nilai tukar sebesar 0.0000 dan nilai tstatistik lebih besar dari t-tabel, dimana hal tersebut menunjukkan bahwa nilai tukar memiliki pengaruh yang signifikan terhadap share price volatility perusahaan yang terdaftar dalam indeks Kompas100. Nilai koefisien variabel nilai tukar adalah sebesar 0.108362 dimana angka tersebut menunjukkan bahwa variabel nilai tukar berpengaruh positif terhadap share price volatility perusahaan yang terdaftar dalam indeks Kompas100. Hubungan postif tersebut menunjukkan bahwa ketika nilai tukar rupiah terhadap dolar melemah (depresiasi) dan nilai dollar meningkat, maka nilai indeks di bursa efek akan cenderung menurun.

Ketika dollar menguat, maka investor akan lebih memilih menginvestasikan modalnya dalam bentuk valas di pasar uang karena akan mendapatkan imbal hasil yang lebih tinggi dibandingkan dengan mengivestasikan modalnya dalam bentuk saham. Selain itu, ketika nilai tukar rupiah terhadap dollar terdepresiasi maka laba perusahaan yang menggunakan bahan baku impor juga akan menurun. Hal tersebut merupakan dampak dari peningkatan harga bahan baku dalam mata uang rupiah yang menyebabkan meningkatnya biaya operasional perusahaan. Biasanya investor cenderung menghindari berinvestasi pada perusahaan yang terkena dampak negatif pelemahan nilai tukar untuk menghindari resiko dan lebih memilih untuk menginvestasikan modalnya dipasar uang untuk mendapatkan keuntungan yang lebih tinggi. Situasi tersebut akan mempengaruhi permintaan saham di pasar modal karena investor akan cenderung menunggu hingga nilai tukar kembali menguat dan situasi pasar membaik. Karena kurangnya transaksi di pasar modal, menyebabkan share price volatility yang rendah dan cenderung menurun.

Hipotesis kedua yang diajukan dalam penelitian ini adalah inflasi berpengaruh signifikan terhadap share price volatility. Berdasarkan hasil regresi yang terlihat pada tabel 4.8, nilai probabilitas variabel inflasi sebesar 0.0002 dimana angka tersebut menunjukkan bahwa inflasi memiliki pengaruh yang signifikan terhadap share price volatility perusahaan yang terdaftar dalam indeks Kompas100. Nilai koefisien variabel inflasi adalah sebesar 0.290577 dimana angka tersebut menunjukkan bahwa variabel inflasi berpengaruh positif terhadap share price volatility perusahaan yang terdaftar dalam indeks Kompas100. Ketika angka inflasi meningkat maka akan berdampak pada meningkatnya share price volatility. Begitu pula sebaliknya, ketika angka inflasi menurun, maka akan berdampak pula pada menurunnya share price volatility.

Hasil ini didukung oleh penelitian terdahulu yang dilakukan oleh Hugida yang menyebutkan bahwa inflasi memiliki hubungan yang positif terhadap volatilitas harga saham. Hubungan positif tersebut terjadi karena adanya hubungan positif antara inflasi dan suku bunga, karena ketika terjadi peningkatan penawaran uang maka akan terjadi peningkatan suku bunga dan akan berimbas kepada rendahnya harga saham. 
Rendahnya harga saham terjadi karena ketika Bank Indonesia meningkatkan suku bunga, maka beban perusahaan akan bertambah, terutama perusahaan yang memiliki hutang di bank. Beban yang bertambah akan mengurangi laba perusahaan dan tentunya akan berdampak pada tertekannya harga saham. Kenaikan angka inflasi akan mendorong pemerintah untuk memberlakukan kebijakan ekonomi yang lebih ketat dan akan berdampak negatif terhadap harga saham. Dampak negatif tersebut akan medorong investor untuk menjual saham sehingga menyebabkan share price volatility menjadi meningkat.

Hipotesis ketiga dalam penelitian ini adalah volume perdagangan berpengaruh signifikan terhadap share price volatility. Berdasarkan hasil regresi yang terlihat pada tabel 4.8, nilai probabilitas variabel volume perdagangan sebesar 0.0004 dimana angka tersebut menunjukkan bahwa volume perdagangan memiliki pengaruh yang signifikan terhadap share price volatility perusahaan yang terdaftar dalam indeks Kompas100. Nilai koefisien variabel volume perdagangan adalah sebesar 0.008924 dimana angka tersebut menunjukkan bahwa variabel volume perdagangan berpengaruh positif terhadap share price volatility perusahaan yang terdaftar dalam indeks Kompas100. Dapat disimpulkan bahwa jika variabel volume perdagangan meningkat 1 lembar saham dan variabel independen lainnya konstan, maka share price volatility akan meningkat sebesar $0.008924 \%$.

Berdasarkan hasil uji parsial, ditemukan bahwa Volume perdagangan memiliki hubungan yang positif dengan share price volatility. Jika volume perdagangan meningkat maka akan menyebabkan share price volatility juga meningkat. Begitu pula sebalknya, jika volume perdagangan menurun akan menyebabkan share price volatility juga akan menurun. Volume perdagangan menunjukkan jumlah lembar saham yang ditransaksikan pada periode tertentu. Volume perdagangan dapat digunakan sebagai acuan untuk melihat bagaimana reaksi pelaku pasar terhadap berbagai informasi serta dampak dari berbagai kejadian. Volume perdagangan yang kecil menunjukkan bahwa investor tidak tertarik untuk berinvestasi pada saham tersebut. Demikian pula Jika suatu saham lebih sering ditrasaksikan di pasar, maka dapat diartikan bahwa saham tersebut sangat aktif dan banyak diminati oleh investor sehingga harga saham menjadi sangat fluktuatif

Hipotesis keempat dalam penelitian ini adalah dividend payout ratio berpengaruh signifikan terhadap share price volatility. Berdasarkan hasil regresi yang terlihat pada tabel 4.8, nilai probabilitas variabel dividend payout ratio sebesar 0.0074 dimana angka tersebut menunjukkan bahwa dividend payout ratio memiliki pengaruh yang signifikan terhadap share price volatility perusahaan yang terdaftar dalam indeks Kompas100. Nilai koefisien variabel volume perdagangan adalah sebesar -0.032649 dimana angka tersebut menunjukkan bahwa variabel dividend payout ratio berpengaruh negatif terhadap share price volatility perusahaan yang terdaftar dalam indeks Kompas100. Dapat disimpulkan bahwa jika variabel dividend payout ratio meningkat $1 \%$ dan 
variabel independen lainnya konstan, maka share price volatility akan menurun sebesar $0.032649 \%$.

Berdasarkan hasil uji parsial, menunjukkan bahwa dividend payout ratio memiliki hubungan yang negatif dengan share price volatility. Jika dividend payout ratio suatu perusahaan meningkat, maka akan menyebabkan share price volatility menurun. Begitu pula sebaliknya, ketika dividend payout ratio menurun maka akan menyebabkan share price volatility meningkat. Rasio pembayaran dividen dapat dijadikan tolak ukur untuk memprediksi pertumbuhan perusahaan serta kesempatan investasi bagi investor. Perusahaan yang memiliki likuiditas yang tinggi serta memiliki cadangan kas yang melimpah, tidak akan ragu untuk membagikan dividen dalam jumlah yang besar. Tingginya rasio pembayaran dividen mengindikasikan bahwa perusahaan dalam keadaan stabil, sehingga investor lebih memilih untuk memegang sahamnya yang akhirnya berdampak terhadap menurunnya share price volatility perusahaan tersebut.

Hipotesis kelima dalam penelitian ini adalah nilai tukar, inflasi, volume perdagangan, dan dividend payout ratio berpengaruh signifikan terhadap share price volatility. Pada tabel 4.8 diperoleh hasil F-statistik sebesar 0.000000 yang menunjukkan bahwa nilai tersebut lebih kecil dari 0.05 . Oleh karena itu, dapat disimpulakan bahwa seluruh variabel independen dalam penelitian ini secara bersama-sama mempengaruhi variabel dependen.

\section{KESIMPULAN}

Penelitian ini dilakukan pada 23 perusahaan yang terdaftar dalam indeks Kompas100 selama periode 2014 - 2018 membahas tentang pengaruh nilai tukar, inflasi, volume perdagangan, dan dividend payout ratio terhadap share price volatility. Berdasarkan pengujian dan pembahasan yang telah dilakukan sebelumnya, penelitian ini menghasilkan beberapa kesimpulan sebagai berikut:

Nilai tukar berpengaruh positif dan signifikan terhadap share price volatility perusahaan yang terdaftar dalam indeks Kompas100 tahun 2014 - 2018. Hal ini dibuktikan dengan nilai probabilitas sebesar $0.0000<0.05$ dan nilai koefisien sebesar 0.108362 , sehingga $\mathrm{H}_{1}$ yang menyatakan bahwa nilai tukar berpengaruh signifikan terhadap share price volatility diterima.

Inflasi berpengaruh positif dan signifikan terhadap share price volatility perusahaan yang terdaftar dalam indeks Kompas100 tahun 2014 - 2018. Hal ini dibuktikan dengan nilai probabilitas sebesar $0.0002<0.05$ dan nilai koefisien sebesar 0.290577 , sehingga $\mathrm{H}_{2}$ yang menyatakan bahwa Inflasi berpengaruh signifikan terhadap share price volatility diterima.

Volume perdagangan berpengaruh positif dan signifikan terhadap share price volatility perusahaan yang terdaftar dalam indeks Kompas100 tahun 2014 - 2018. Hal ini dibuktikan dengan nilai probabilitas sebesar $0.0004<0.05$ dan nilai koefisien 
IHTIYATH Jurnal Manajemen Keuangan Syariah

Vol. 5 No. 1, September 2021

sebesar 0.008924, sehingga $\mathrm{H}_{3}$ yang menyatakan bahwa volume perdagangan berpengaruh signifikan terhadap share price volatility diterima.

Dividend payout ratio berpengaruh negatif dan signifikan terhadap share price volatility perusahaan yang terdaftar dalam indeks Kompas100 tahun 2014 - 2018. Hal ini dibuktikan dengan nilai probabilitas sebesar $0.0074<0.05$ dan nilai koefisien sebesar -0.032649 , sehingga $\mathrm{H}_{4}$ yang menyatakan bahwa dividend payout ratio berpengaruh signifikan terhadap share price volatility diterima.

Secara simultan variabel nilai tukar, inflasi, volume perdagangan dan dividend payout ratio berpengaruh signifikan terhadap share price volatility perusahaan yang terdaftar dalam indeks Kompas100 tahun 2014 - 2018. Hal ini dibuktikan dengan nilai probabilitas F-statistik sebesar $0.000000<0.05$ dan nilai adjusted $R$ square sebesar 0.416174 , sehingga $\mathrm{H}_{5}$ yang menyatakan bahwa nilai tukar, inflasi, volume perdagangan dan dividend payout ratio secara bersama-sama berpengaruh signifikan terhadap share price volatility diterima.

\section{DAFTAR PUSTAKA}

Alwi, Iskandar Z., 2003, "Pasar Modal Teori dan Aplikasi”, Jakarta: Yayasan Pancur Siwah.

Arikunto, Suharsimi, 2006, Prosedur Penelitian Suatu Pendekatan Praktik, Jakarta : Rineka Cipta,.

Boediono, 2005, “Ekonomi Moneter", Yogyakarta: BPFE-Yogyakarta.

Hadi, Nor, 2013, "Pasar Modal (Acuan Teoretis dan Praktisi Investasi di Instrumen Keuangan Pasar Modal)", Yogyakarta : Graha Ilmu.

Harsono, Ardelia Rezeki dan Saparila Worokinasih, 2018, "Pengaruh Inflasi, Suku Bunga, dan Nilai Tukar Rupiah Terhadap Indeks Harga Saham Gabungan (Studi Pada Bursa Efek Indonesia Periode 2013-2017)", Jurnal Administrasi Bisnis (JAB) Vol.60 No.2 Juli.

Juliandi, Azuar dan Irfan, 2013, Metodologi Penelitian Kuantitatif Untuk Ilmu-ilmu Bisnis, (Bandung: Citapustaka Media Perintis.

Kewal, Suramaya Suci, 2012, "Pengaruh Inflasi, Suku Bunga, Kurs, dan Pertumbuhan PDB Terhadap Indeks Harga Saham Gabungan“, Jurnal Economia, Vol.8 No.1, April.

Nasir, Jamli La, dkk, 2018, “Analisis Faktor-faktor Yang Mempengaruhi Volatilitas Harga Saham (Studi Kasus Pada Perusahaan LQ45 Yang Terdaftar Di Bursa Efek Indonesia Periode 2012-2016)", E-JRA Vol. 07 No. 09 Agustus.

Rifai, Veithzal, dkk, 2007, "Bank dan Financial Institution Management”, Jakarta: PT Raja Grafindo Persada.

Rohmawati, Irma, 2016, "Pengaruh Volume Perdagangan, Dividend Payout Ratio, dan Inflasi Terhadap volatilitas Harga Ssaham Pada Perusahaan Yang Terdaftar Dalam Indeks LQ45 Tahun 2011-2015”, Skripsi, Yogyakarta: Universitas Negeri Yogyakarta. 
Sartono, Agus, 2001, “Manajemen Keuangan Teori dan Aplikasi”, Yogyakarta: BPFEYogyakarta.

Suad, Husnan, 2008, "Manajemen Keuangan: Teori dan Penerapan”, Buku 1, Edisi 4, Yogyakarta: BPFE-Yogyakarta.

Sugiono, 2014, Metode Penelitian Manajemen, Cet. Ketiga, Bandung: Penerbit Alfabeta.

Sukirno, Sadono, 2003, “Makro Ekonomi Modern”, Jakarta: Raja Grafindo Persada.

Sutrisno, Bambang, 2017, "Hubungan Volatilitas dan Volume Perdagangan di Bursa Efe" Jurnal Bisnis dan Manajemen, Vol.7, No.1, April.

Umam, Khaerul, 2013, "Pasar Modal Syariah dan Praktik Pasar Modal Syariah", Bandung: CV Pustaka Setia.

Waluyo, Wawan, 2016, “Analisis Determinan Volatilitas Harga Saham”, Skripsi, Universitas Negeri Yogyakarta: Jurusan Manajemen.

https $/ /$ www.bi.go.id/id/statistik/informasi-kurs/transaksi-bi/Default.aspx

https//www.bi.go.id/statistik/indikator/data-inflasi.aspx

https/finance. yahoo.com/quote/KOMPAS100.JK/hitory?p

https $/ /$ www.idx.co.id/produk/indeks/

https//id.investing.com/indices/kompas-100-historical-data

https $/ /$ www.sahamok.net/bei/indeks-bursa/indeks-kompas-100/\#Indeks_Bursa 